\title{
Reply to Castro et al. 2018 on "Holocene paleo-sea level changes along the coast of Rio de Janeiro, southern Brazil".
}

\author{
RODOLFO J. ANGULO ${ }^{1}$, PAULO C.F. GIANNINI', MARIA CRISTINA \\ DE SOUZA ${ }^{1}$ and GUILHERME C. LESSA ${ }^{3}$ \\ ${ }^{1}$ Centro Politécnico, Departamento de Geologia, UFPR, Laboratório de Estudos Costeiros/Lecost, Av. \\ Cel. Francisco H. dos Santos, 210, Jardim das Américas, 81531-970 Curitiba, PR, Brazil \\ ${ }^{2}$ Instituto de Geociências, USP, Rua do Lago, 562, Cidade Universitária, 05508-080 São Paulo, SP, Brazil \\ ${ }^{3}$ Grupo de Oceanografia Tropical/GOAT, UFBA, Travessa Barão de Jeremoabo, s/n, Campus \\ Universitário de Ondina, LFNA, Sala 02, 40170-280 Salvador, BA, Brazil
}

Manuscript received on April 19, 2018; accepted for publication on April 19, 2018

\begin{abstract}
Discussions are useful to the advance of science, and we appreciate the opportunity to discuss the paper by Castro et al. (2014) for the second time. Here we maintain the interpretations presented in our discussion paper (Angulo et al. 2016). In the discussion paper we emphasized that the vertical position of a paleo-sea level indicator is not the position of the paleo-sea level. We pointed out that: (1) to reconstruct paleo-sea levels it is crucial to determine the vertical distance between the indicators to their present homologous one; (2) margin of errors can only be established if considering the indicator's intrinsic characteristics and (3) the interpretation of a sea level 3.0 to $4.5 \mathrm{~m}$ below the present one at 11.9 to- $11.1 \mathrm{ka}$ BP is in strong contradiction with worldwide established data and would require a detailed discussion. We consider that Castro et al. (2018) do not properly address or answer the comments we made in the discussion paper. More work and discussions are necessary to elucidate several questions that still remain about the sea level behavior in the Holocene.
\end{abstract}

Key words: beachrock, vermetids, relative sealevel indicators, method of relative sealevel reconstruction.

\section{INTRODUCTION}

Sealevel higher than present along the Brazilian coast were recognized by pioneer researchers. Hartt (1870) described sea urchin holes elevated above the present living zone at Rio de Janeiro coast and Branner (1902) at Pernambuco coast. The first datings confirming Holocene sealevels higher than present were published at the seminal

Correspondence to: Rodolfo José Angulo

E-mail: fitoangulo@gmail.com paper by Van-Andel and Laborel (1964) on the State of Pernambuco coast. Also at that time the monumental work of Fairbridge (1961) was published with global sea-level curves. This paper issued a large discussion on the existence of small eustatic oscillations since the middle Holocene, with authors pointing out to the broad disparities of Holocene sea level curves around the world (e.g. Pirazzoli 1996). The first sketch of a curve in Brazil was published in 1975 with sparse data from Cananeia, and in 1980 the first paleo-sea level 
curve was published for the region of Salvador. In 1985 new curves were presented for the States of Pernambuco and Santa Catarina. These curves were widely accepted, and some divergences appeared in the 1990's and others in the first decade of the XXI century (see Angulo et al. 2006). After that a new curve for Rio de Janeiro was published by Castro et al. (2014) which generated our (Angulo et al. 2016) and Castro et al. (2018) comments and the present reply.

\section{DISCUSSION}

As Edgard Morin (1996) wrote, "(Karl) Popper changed the science perspective; it was believed that science advanced by accumulating truths; he showed that progress is achieved especially by eliminating errors in the search of truth". The power of the scientific method is that it allows for the advance of knowledge independently of an individual researcher's opinions. We believe that this ongoing discussion will contribute to improve the understanding of paleo-sea level changes along the Brazilian coast.

Here we maintain the interpretations presented in our discussion paper (Angulo et al. 2016). The main issue amongst those raised in our paper, and which was not properly addressed in the reply, was the methodology used by Castro et al. (2014) to determine paleo-sea levels. They write: "The margin of error for the sample altitudes was minimal. Several investigations conducted on the South American coasts regarding relative sea-level variations have not clearly or precisely defined the reference level of the samples used in the vertical plane (...). The absence of this information yields potential inaccuracies regarding the height of the marine paleo-levels of the proposed curves. (...) Secondly, the method employed in this study would need to be applied to other parts of the Brazilian coastline". In the discussion paper we pointed out that the vertical position of a paleo- sea level indicator (e.g. biological remain or facies contact) is not the position of the paleo-sea level. To reconstruct paleo-sea levels it is crucial to determine the relationship of a given indicator to the present homologous one. In this way relative paleo-sea levels can be inferred without knowing the elevation of the mean sea level or other datum. Alternatively, the paleo-sea level can also be determined adding (or subtracting) the altitude of the indicator to the altitude (or depth) of the present homologous indicator, but this was not made by Castro et al. (2014), who simply took the elevation of the remains or sedimentary deposits and assumed that those altitudes corresponded to paleo-sea levels.

Castro et al. (2018) make two incorrect statements, being 1) "Angulo et al. (2006a, 2016b) do not explain, from the methodological point of view, how vermetids altimetric position were obtained. By convenience it was used other authors altimetric information"; and 2) "altimetric data were positioned based on global model of geophysical simulation" Again, Angulo's et al (2006) paper did not address the altimetry of the paleo-sea level indicators. That paper explains in detail how each relative paleo-sea level was obtained from each indicator, after measuring the vertical distance between the indicators to their present homologous one. We did not use the global altimetry model to determine the elevation of our samples; we compared the empiric data with the modeled curve to show how well they fit.

Another important point in our discussion paper regards the margin of error, which can only be established if considering the indicator's intrinsic characteristics. For example, the vermetid vertical distribution is affected by wave energy and coastal morphology (Delibrias and Laborel 1969). Therefore, changes in any of these characteristics since the lifetime of ancient vermetids can enlarge the error margin on paleo-sea level estimates (Angulo et al. 1999, Angulo and Souza 2014). 
Also the vermetid remains may not correspond to the upper limit of living vermetids and can also increase the error (Angulo et al. 1999).

We agree with Castro et al. (2018) that the vermetids vertical position varies with the species, which in turn vary along the Brazilian coast, as defined by Spotorno-Oliveira et al. (2012). Whenever possible Angulo (1993) and Angulo et al. $(1999,2002)$ compared the paleo remains with their homologous (same specie) one. When bioconstructions of living Petaloconchus varians was not found (as in southern São Paulo, Paraná and Santa Catarina coasts), the Phragmatopoma lapidosa (a subjective synonym of Phragmatopoma caudata) was used as an homologous because the highest elevation of their bioconstructions are similar on rocky coasts (Angulo et al. 1999).

We also agree with Castro et al. (2018) on their general comments on beachrocks, but we point out that to infer a paleo-sea level from a beachrock it is necessary to identify their facies and facies contacts, as well as to measure the vertical distance between the ancient and present homologous facies contacts (e.g. Hart 1870, Angulo et al. 2006). In addition, it should also be taken into consideration that the time of deposition could differ from the age of the bioclasts and the cement (Angulo et al. 2013, Angulo and Souza 2014). Castro et al. (2014) did not consider these aspects, which are critical for their assertion: "for the first time on the Brazilian coast it was identified a negative record of relative sea-level during Late Pleistocene and Early Holocene transition". The interpretation of a sea level 3.0 to $4.5 \mathrm{~m}$ below the present one at 11.9 to $11.1 \mathrm{ka}$ (Beta Analytic n 248722 and 248721) BP is in strong contradiction with worldwide established data (Pirazzoli 1996) for this time period, and would require a detailed discussion. Because this discussion is absent, it is fair to assume their paleo-sea level interpretation based on beachrock altimetry and isotopic datating is not robust enough to sustain such a claim. We agree with the conclusion of Spotorno-Oliveira et al. (2016, with Castro as one of the co-authors), who after studying that same area in Rio de Janeiro and analyzing samples with similar ages (from 13,130 to 11,149 cal. years BP) and depths (- 4.5 to $+1.5 \mathrm{~m})$, stated: "The altitude of the studied grainstone (...) confirms that these samples formed in a high hydrodynamic energy setting that cannot be related to the sea level at that age".

We consider that Castro et al. (2018) do not properly address or answer all the comments we made in the discussion paper. More work and discussions are necessary to elucidate several questions that still remain about the sea level behavior in the Holocene.

\section{REFERENCES}

ANGULO RJ, GIANNINI PCF, SUGUIO K AND PESSENDA LCR. 1999. The relative sea-level changes in the last 5500 years southern Brazil (Laguna-Imbituba region, Santa Catarina State) based on vermetid 14C ages. Mar Geol 159: 327-339.

ANGULO RJ, LESSA GC AND SOUZA MC. 2006. A critical review of mid- to late-Holocene sea-level fluctuations on the eastern Brazilian coastline. Quat Sci Rev 25: 486-506.

ANGULO RJ AND SOUZA MC. 2014. Revisão conceitual de indicadores costeiros de paleoníveis marinhos quaternários no Brasil. Quat Environ Geosci 05(2): 01-32.

ANGULO RJ, SOUZA MC, FERNANDES LAAND DISARÓ ST. 2013. Quaternary sea-level changes and aeolianites in the Fernando de Noronha archipelago, northeastern Brazil. Quat Int 305: 15-30.

ANGULO RJ, GIANNINI PCF, SOUZA MC AND LESSA GC. 2016. Holocene paleo-sea level changes along the coast of Rio de Janeiro, southern Brazil: Comment on Castro et al. (2014). An Acad Bras Cienc 88: 2105-2111.

BRANNER JC. 1902. Geology of northeast coast of Brazil. Bull Geol Soc Am 13: 41-98.

CASTRO JWA, SUGUIO K, SEOANE JCS, CUNHA AM DA AND DIAS FF. 2014. Sea-level fluctuations and costal evolution in the state of Rio de Janeiro southeastern Brazil. An Acad Bras Cienc 86: 671-683.

CASTRO JWA, SEOANE JCS, CUNHA AM DA, MALTA JV AND SUGUIO K. 2018. Comments to Angulo et al. 2016 on "Sea-level fluctuations and coastal evolution in the state of Rio de Janeiro, southeastern - Brazil" by Castro et al. 2014. An Acad Bras Cienc 88. 
DELIBRIAS G AND LABOREL J. 1969. Recent variations of the sea level along the Brazilian coast. Quaternaria 14: 45-49.

HARTT CF. 1870. Geology and physical geography of Brazil. Fields, Osgood \& Co., Boston, 620 p.

FAIRBRIDGE RW. 1961. Eustatic changes in sea level. Phys Chem Earth 4: 99-185.

MORIN E. 1996. Ciência com Consciência. Bertrand, Rio de Janeiro, $336 \mathrm{p}$.

PIRAZZOLI PA. 1996. Sea-level changes: The last 20000 years. J Wiley \& Sons, $211 \mathrm{p}$.
SPOTORNO-OLIVEIRA P, TÂMEGA FTS, OLIVEIRA CA, CASTRO JWA, COUTINHO R, IRYUC Y AND BASSI

D. 2016. Effects of Holocene sea level changes on subtidal palaeoecosystems, southeastern Brazil. Mar Geol 381(1): 17-28.

SPOTORNO P, TÂMEGA FTS AND BEMVENUTI CE. 2012. An overview of the recent vermetids (Gastropoda: Vermetidae) from Brazil. Strombus 19(1-2): 1-8.

VAN ANDEL TH AND LABOREL J. 1964. Recent high relative sea level stand near Recife, Brazil. Science 145: 580-581. 